NEWS

\title{
China outlines deep-sea ambitions
}

\section{Extra funding promised to help search for natural resources and advance ocean research.}

\section{SHANGHAI, CHINA}

China is setting its sights on exploring and exploiting the deep sea. Until recently, the country's ocean research focused largely on coastal and offshore waters. But with its breakneck economic development demanding ever more resources, and a growing desire to have more influence in territory disputes and international waters, China is investing heavily in its deep-sea research and exploration programme, experts revealed at a meeting in Shanghai last week.

The move will be reflected in the country's next five-year budget plan, beginning in 2011, with increased funding for oceanography, especially research and development of deepsea technology, says Baohua Liu, a geophysicist at China's State Oceanic Administration (SOA). Liu will head a newly approved deep-sea centre in Qingdao, Shandong province in eastern China. Construction will begin next year and is expected to take about three years.

The funding boost is largely motivated by China's hunt for oil and minerals, and some scientists worry that research may be sidelined by commercial goals. Others say resource exploration and basic science can coexist. "The strategic shift is extremely far-sighted," says Jian Lin, a marine geologist at the Woods Hole Oceanographic Institution (WHOI) in Massachusetts, one of some 500 participants at the First Conference on Deep-Sea Research and Earth Systems Science. "It is emblematic of the country as a rising world power, on a par with its space programme and polar research."

China's deep-sea ambitions have been bolstered by discoveries from scientists onboard Dayang Yihao, the country's main ocean exploration vessel. They have studied the very slowly spreading Southwest Indian Ridge (SWIR) in the southern Indian Ocean. The ridge separates the African plate to the north from the Antarctic plate to the south and is likely to contain rocks from deep within Earth's mantle.

In 2007, a team led by Lin and Tao Chunhui, a geophysicist at the SOA's Second Institute of Oceanography (SIO) in Hangzhou, Zhejiang province in eastern China, discovered the first active hydrothermal vent on the SWIR, ending a debate on whether ultraslow-spreading ridges can sustain hydrothermal activity. And earlier this year, geologists at the SIO and Peking University conducted the first large-scale oceanbottom seismic experiments on the SWIR, looking for a potential magma chamber in the crust

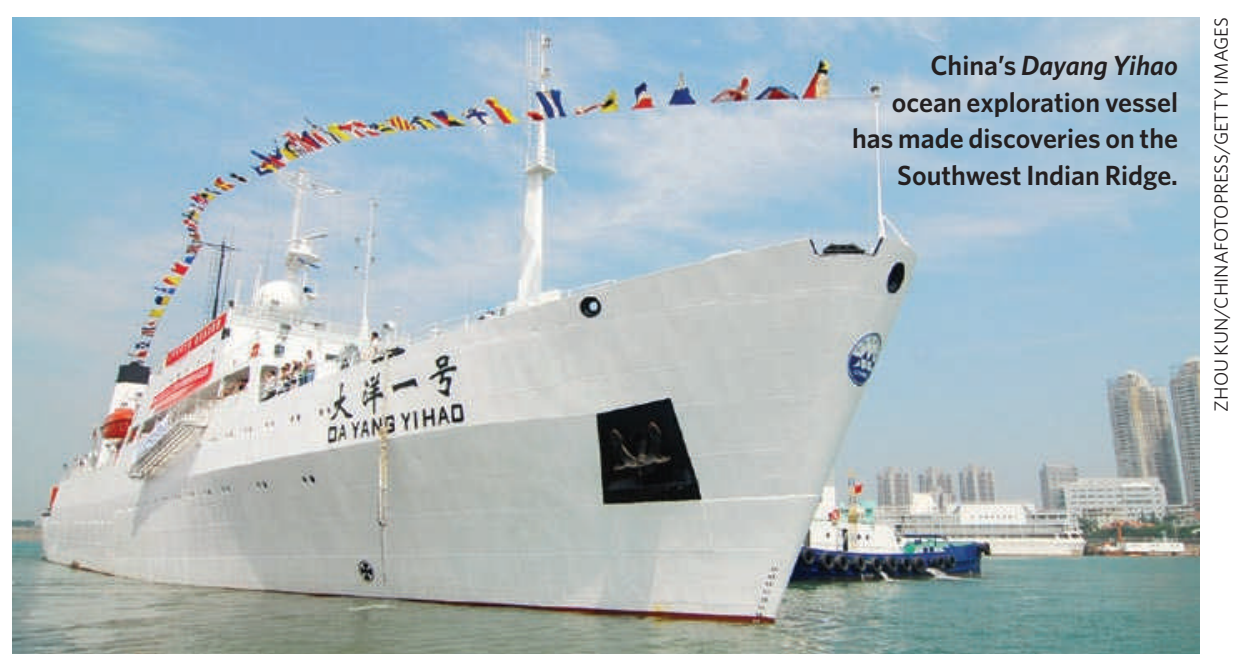

to understand how it drives ridge spreading.

These forays into deep water also highlighted weaknesses in the country's remote-sensing and submarine capabilities, says Zhou Huaiyang, a geologist at Tongji University in Shanghai. So China has boosted funding on deep-sea technology, especially underwater vehicles. Last week, researchers descended 3,000 metres in the South China Sea in Harmony, a submersible designed to dive to 7,000 metres - 500 metres deeper than Japan's Shinkai submersible.

Scientists also say that research efforts should be better coordinated. Different institutions are funded by different agencies and often work on overlapping projects, with little sharing of data and research vessels. "This is not an effective way of doing oceanic science at a time when multiinstitutional and international collaborations are increasingly crucial," says Wang Pinxian, a marine geologist at Tongji, who co-chaired the meeting. Wang is vice-chair of the Chinese scientific committee of the international Integrated Ocean Drilling Program (IODP).

Ultimately, scientists say, China should build its own deep-sea drilling vessel and become a full member of the IODP, which would cost about US\$6 million a year. Wang and his collaborators have already partnered with the IODP in palaeoceanography studies of the South China Sea, drilling cores to study Earth's early climate. These data have proved useful for the China National Offshore Oil Corporation in Beijing, says Wang. With extra funding of $\$ 22$ million now expected from China's National Natural Science Foundation, Wang hopes the programme will expand to study ocean-crust evolution, deep-sea sedimentation and the marine biosphere. The researchers eventually want to build a network of ocean-floor observatories in the South China Sea, similar to the US Ocean Observatories Initiative and NEPTUNE Canada (see Nature 464, 1115; 2010).

\section{The right balance}

Although they welcome the increased investment, Wang and others worry that research could be hampered by a focus on finding new sources of oil and minerals. Scientists onboard research vessels such as Dayang Yihao are there primarily to fulfil that purpose. Ship time and funding for curiosity-driven research still seem hard to come by. Many believe that China's SWIR work took place in spite of, rather than because of, this resource-driven approach, and probably wouldn't have happened without collaborations with top research institutions such as the WHOI.

Lin points out that basic research is key to finding new resources, noting that the SWIR research helped to find sulphide deposits rich in copper, lead and zinc. As soon as the International Seabed Authority adopted regulations this May for prospecting for polymetallic sulphides, China applied to explore the SWIR. "Without solid research and science-driven technological innovation, resource searching would ultimately be futile," says Lin.

If China can get the balance between research and commercial exploration right, Wang says, the future is bright. "An ingenious combination of the two will create a win-win situation." Jane Qiu 